\title{
Ilomata International Journal of Social Science
}

P-ISSN: 2714-898X; E-ISSN: 2714-8998

Volume 3, Issue 1 January 2022

Page No. 61-73

\section{Accessibility for Persons with Disabilities in Employment Opportunities in Private Companies: A Case Study of Indonesia}

\author{
${ }^{1}$ Baby Poernomo, ${ }^{2}$ Charles Magwari Omboto, ${ }^{3}$ Jeruth Ngonzi Tinka \\ ${ }^{1}$ Institut Ilmu Sosial dan Manajemen STIAMI, Indonesia \\ ${ }^{2}$ Kenya Institute of Special Education, Kenya \\ ${ }^{3}$ Ministry of Education and Sports, Uganda \\ Correspondent: babypoernomo1966@gmail.com ${ }^{1}$
}

$\begin{array}{ll}\text { Received } & \text { : August 26, } 2021 \\ \text { Accepted } & \text { : January 15, } 2022 \\ \text { Published } & \text { : January 31, } 2022\end{array}$

Citation: Poernomo, N., Omboto, C, M., Tinka, J, N. (2022). Accessibility for Persons with Disabilities in Employment

Opportunities in Private Companies: A Case Study of Indonesia. Ilomata International Journal of Social Science, 3(1), 61-73.

https://doi.org/10.52728/ijss.v3i1.413
ABSTRACT: The absorption of workers with disabilities in Indonesia is still limited. The companies argue that it is difficult to meet accessibility for disabled workers because it requires a lot of funds, for instance facilities that need to be made so that the workplace accessible for people with disabilities. This research is aimed at answering the questions of how the accessibility of persons with disabilities in employment opportunities in private companies in Indonesia, what obstacles encountered by persons with disabilities who work in private companies, and how the solutions are provided so that persons with disabilities have easy access to work in private companies. This is a qualitative research with a case study approach. The data collection in this study used semi-structured interviews with 20 people with disabilities consists of 10 people with disabilities who were rejected by companies and 10 people with disabilities who had been accepted to work but finally decided to quit. In this study, a public policy expert was also interviewed to obtain data on how policies related to persons with disabilities were implemented. The results of this study indicate that there are still many people with disabilities who are rejected to work by the companies. If anyone is already working, eventually they have to resign considering the unequal treatment they have received, both from the leaders and fellow employees. However, until now there has never been a company that got a sanction even though the regulations regarding the treatment of persons with disabilities have been affirmed in Law Number 8/2016. Therefore, stricter supervision is needed for private companies so that they not only fulfill the quota of $1 \%$ of employees with disabilities out of the total number of employees, but also pay attention and treat employees with disabilities the same as other employees.

Keywords: Accessibility, persons with disabilities, employment opportunities, public policies. 


\section{INTRODUCTION}

Persons with Disabilities in Indonesia still experience obstacles in accessibility to the world of work (P. S. Putra, 2019). In addition to the problem of limited employment opportunities, people with disabilities are also still constrained by problems of discrimination and stigma (Nuraviva et al., 2018). The Central Bureau of Statistics (BPS) in 2020 released data on persons with disabilities of working age, which amounted to 17.74 million people. Of these, 7.8 million people are included in the labor force category (Budiati et al., 2020). When compared with the national labor force participation rate of $69 \%$, the labor force participation rate of persons with disabilities is only around $44 \%$ whereas government offices, regional governments, BUMN, and BUMD are required to employ at least $2 \%$ of people with disabilities, as stated in Law Number 8/2016, Article 53. Meanwhile, private companies also have an obligation to employ at least $1 \%$ of people with disabilities (Budiati et al., 2020).

The work participation rate of people with disabilities in Indonesia is still low, but this does not mean that there is no hope for people with disabilities to be able to work in the formal sector (Wardani et al., 2015). Currently, the ILO has even provided guidelines on the Management of Persons with Disabilities in the Workplace in accordance with ILO Convention No. 159/1983, for agencies or companies that will start employing persons with disabilities (Jackson et al., 2021). The purpose of making this guideline is that agencies or companies can seek safety in the workplace, a healthy atmosphere and workplace, minimize expenses for companies that employ people with disabilities, and optimize the contribution of people with disabilities to companies (Ordway et al., 2021).

The presence of Law No. 8/2016 provides a new paradigm for guaranteeing and protecting the rights of persons with disabilities. People with disabilities were previously placed as objects, as stated in Law No. 4/1997, so in the new law, people with disabilities have a place as subjects. Of course, with the presence of this new law, there are consequences that must be implemented both by the central government and local governments in terms of providing facilities and infrastructure (Widyawati et al., 2021).

In terms of fulfilling the right to obtain decent work, persons with disabilities must face several challenges including the stigma that people with disabilities are not socially and economically productive (Wahyuni, 2019). This greatly affects the employee recruitment process in both government and private institutions, especially at this time physical and spiritual health factors are still the main requirement in the employee recruitment process (Susanto \& Sudiro, 2018). This is also related to the company's ability to manage the diversity of its workforce. Managing the diversity of the workforce in a company is a challenge for the company (Pertiwi et al., 2020).

Another thing is that there are still many office buildings that are not friendly for people with disabilities. Companies often use this as an excuse to reject persons with disabilities because if they are going to recruit them, it means that the company has to spend quite a lot of money to fulfill workplace facilities and infrastructure. Although Law No. 8/2016, Article 11 has confirmed the sanctions, namely imprisonment for a maximum of 2 years and a maximum fine of Rp. 200 million for anyone who hinders and/or prohibits persons with disabilities from obtaining the right to work (Wardani et al., 2015). 
In addition, there are still many people and institutions that have not been able to appreciate differences. This is also related to career development and increasing employee salaries, and the supervisory system related to compliance with companies that employ people with disabilities is still very weak. To date, there is no special agency that functions to oversee private companies employing persons with disabilities (Stillman et al., 2021).

The discriminatory treatments against persons with disabilities above show that the law enforcement is still ineffective. Based on the problems above, this study aims to answer the questions: (1) How is the accessibility of persons with disabilities in employment opportunities in private companies, (2) What are the obstacles encountered by persons with disabilities who work in private companies, (3) What are the solutions provided so that persons with disabilities have easy access to work in private companies. The results of this study will provide valuable input for private companies in Indonesia so that they can comply with the policies that have been made by the government regarding accessibility for persons with disabilities to enter the workforce and can be input for government agencies authorized to improve the supervision system for companies that reject persons with disabilities and treat employees with disabilities arbitrarily (Larocca et al., 2020).

Person with a disability is someone who has a disorder and/or who can interfere with activities (Havercamp et al., 2021). If a child has something special or extraordinary that is not found in his age are called children with special needs. As for something extraordinary, it is not always positive, but there is also something negative (Bourke et al., 2021). Families, communities, the environment, companies and the government must provide support in various fields such as education, health, employment and social services, which from a human rights perspective are categorized as special rights for certain community groups (Cho \& Kim, 2021). Children with disabilities or often referred to as children with special needs are children who are in the process of growth or development significantly experiencing abnormalities or deviations compared to other children their age (Triutari, 2014). Discrimination occurs when 'labeling' such as the word 'disability' occurs as a form to distinguish or exclude (Nursyamsi et al., 2015).

The World Health Organization (WHO) defines disability as a state of limited ability to carry out activities within the limits that are considered normal. There are 3 categories of disability proposed by WHO as shown in figure 1 below:

Figure 1 Disability Category

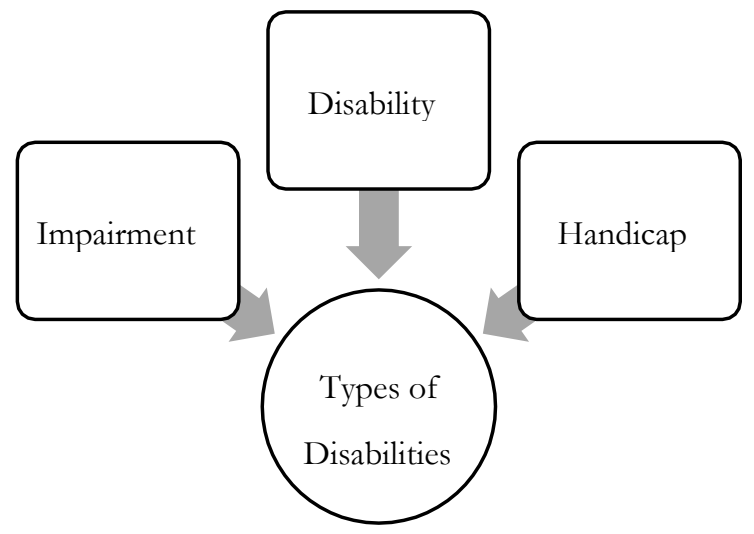

Source: World Health Organization (2015) 
(a). Impairment is an abnormal condition or loss of psychological or anatomical structure or function; (b). Disability is the inability or limitation as a result of an impairment to carry out activities in a way that is considered normal for humans; (c). Handicap is a condition that is detrimental to a person due to an impairment and disability that prevents him or her from fulfilling a normal role (in the context of age, gender, and cultural factors) for the person concerned (Centers for Disease Control and Prevention, 2020; World Health Organization, 2015).

Meanwhile, Law No. 8/2016 states that anyone who experiences physical, intellectual, mental, and/or sensory limitations in the long term who interacts with the environment can experience obstacles and difficulties to participate fully and effectively with citizens. Others based on equal rights are called disabilities (Paikah, 2017).

Persons with disabilities are part of Indonesian society who also have the same position, rights, obligations, opportunities and roles in all aspects of life and livelihood. This recognition has been legally strengthened through Law No. 8 of 2016 concerning Persons with Disabilities, which stipulates that (1) The Government, Regional Governments, State-Owned Enterprises, and Regional-Owned Enterprises are required to employ at least 2\% (two percent) of Persons with Disabilities. Disabilities from the number of employees or workers; (2) Private companies are required to employ at least 1\% (one percent) of Persons with Disabilities from the total number of employees or workers. The sanctions are not kidding. If violated, a maximum penalty of 6 months and/or a maximum fine of 200 million rupiah will be imposed R. E. Putra, 2020) .

Meanwhile, the facilities provided for persons with disabilities with the aim of providing equal opportunities are known as 'accessibility' as written in Article 1 of the Law on Persons with Disabilities. Furthermore, the right of accessibility for persons with disabilities is stated in more detail in Article 19 of the Law on Persons with Disabilities which states that the right of accessibility includes the right to: a. Gaining accessibility to take advantage of public facilities;

b. Get adequate accommodation as a form of individual accessibility (Gerak Inklusi, 2021).

Although there has been a law that regulates equal rights for persons with disabilities, including the right to obtain employment in the formal sector, up to now, companies tend to still recruit quality human resources without disabilities. Injustice can be seen starting from the selection process carried out by the company which states that applicants must be physically and mentally healthy. This problem is often faced by companies starting from the test/selection process carried out (Agustina \& Mahfudz, 2020; Saputra, 2021). This is also related to how companies can manage human resources with disabilities who must respect differences, which by itself will create challenges related to differences in how to communicate with employees with disabilities and also people who still cannot apply objectively to the acceptance of assessments on differences (Amrullah et al., 2018). People with disabilities will also face difficulties in job promotion and increasing wages (Bonnell et al., 2021; Eisenberg et al., 2021).

The equal position of persons with disabilities as citizens with other workers is also clearly stated in Article 5, Law Number 8/2016, where persons with disabilities are stated to have rights in work, entrepreneurship and cooperatives, including the right to obtain work without discrimination and obtain employment. the same wages as non-disabled workers. This law also clearly states that it is forbidden for companies to lay off employees on the grounds of disability 
Accessibility for Persons with Disabilities in Employment Opportunities in Private Companies: A Case Study of Indonesia

Poernomo, Omboto, Tinka

(Pramesty, 2020). The International Labor Organization (ILO) has published guidelines for the Management of Persons with Disabilities in the Workplace (Angeloni, 2013; Beatty et al., 2019). For companies that have never recruited persons with disabilities, they can start with the steps as described in the Guidelines for the Management of Persons with Disabilities, as illustrated in figure 2 below .

Figure 2

Steps for recruitment of persons with disabilities

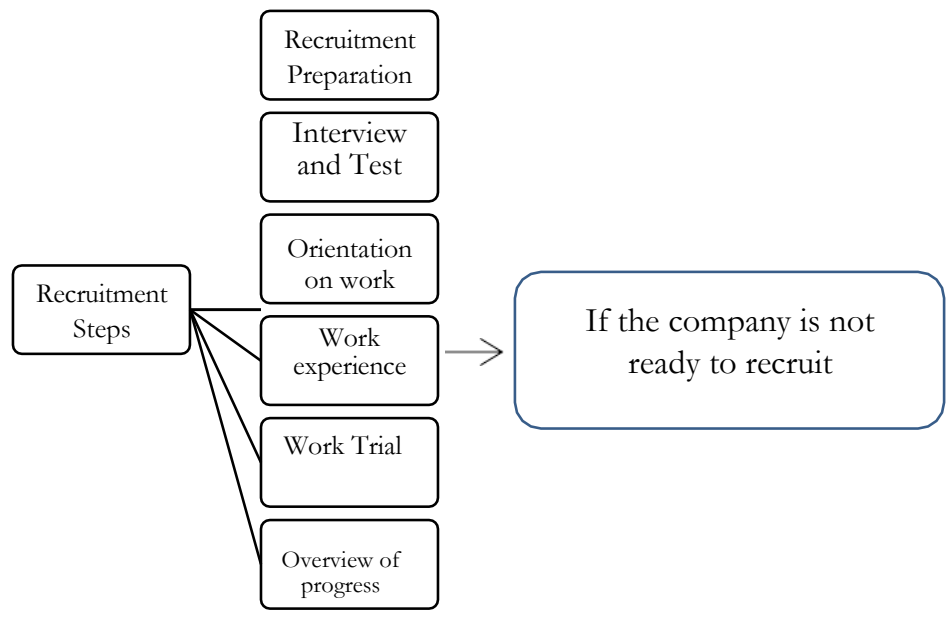

Source: ILO Disability and Work Guideline (스geloni, 2013)

(a) Preparation for recruitment

Employers can consult with providers of employment services for persons with disabilities, or specialized institutions by ensuring that job vacancies are published in a format that is accessible to applicants from various types of persons with disabilities - in publications in print, radio, internet - by providing application materials.

(b) Interview and Test

Pre-employment tests and selection criteria should focus on specific skills, knowledge and abilities deemed essential for the existing job functions. Efforts should be made to select a test whose format is accessible to applicants with disabilities.

(c) Worker orientation on work

Employers should conduct an orientation on the company or service, work environment and employment for each newly recruited worker with disabilities, in the same way as for non-disabled workers.

(d) Work experience

If employers are not ready to employ persons with disabilities, they may consider providing opportunities for work experience for job seekers with disabilities. The goal is that they can acquire the skills, knowledge and work attitudes needed for a particular job in the workplace.

(e) Trial work and placement of supported workers. 
Interested parties should facilitate work experience, trial work and job placement with support through providing technical advice to employers and persons with disabilities, as needed.

(f) Overview of progress.

Employers should continue to review their recruitment process, to ensure that it is accessible to persons with disabilities of different types of disabilities.

For persons with disabilities who are already working in companies, the ILO has also arranged for the next stage of management, as illustrated in Figure 2 below:

Figure 2

Management of persons with disabilities who are already working in the company

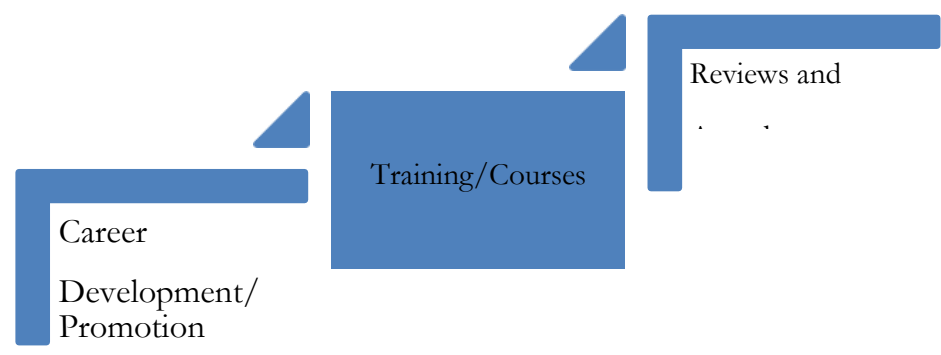

Source: International Labour

Organization (ILO) 2013

(a) Career development and promotion of persons with disabilities working in companies. Workers with disabilities should be given the same opportunities as other workers in the workplace to acquire the skills and experience necessary to advance their careers.

(b) Opportunities for training, and employer-sponsored courses.

In selecting training services and opportunities outside the company, employers should take into account accessibility to training venues for workers with disabilities.

(c) Reviews and Rewards

Rewards for the performance of workers with disabilities must be carried out in accordance with the criteria that apply to holders of the same position.

The law also clearly states the regulations regarding how persons with disabilities must receive treatment, starting from taking the test to carrying out a job which is strictly regulated in its articles (Bam \& Ronnie, 2020). Article 47 states that job providers must provide opportunities for persons with disabilities and not reject arbitrarily on the grounds of disability. After following the selection process and will carry out their work, the company must provide direction and orientation period in order for employees with disabilities to fully understand what, why and how they have to do their work in Article 48. Article 48 also emphasizes that companies must provide the same wages to persons with disabilities as other employees with the same type of work (International Labour Organization, 2013). 


\section{METHOD}

This study uses a phenomenological framework by focusing on exploring the experiences and meanings felt by persons with disabilities when dealing with the world of work. In phenomenology, there are six basic elements that are generally applied when researchers examine a phenomenon, which consist of: (a) study of a phenomenon, (b) study of an essence and the pattern of relationships between essences, (c) study of on the pattern of manifestation of a phenomenon, (d) exploration of the structure of the phenomenon, (e) bracketing, (f) interpretation of the implicit meaning of a phenomenon (Lloyd et al., 2014; Ziakas \& Boukas, 2013). The advantages of phenomenological studies, namely that it can reveal hidden experiences both from the philosophical and psychological aspects of a person which are described in detail through writing so that readers can understand the life experiences experienced by research subjects (Creswell, 2017; Jamali, 2018).

In this study, researchers used semi-structured interviews. This type of interview is included in the in-depth interview category, where the implementation is more free when compared to structured interviews. The purpose of this type of interview is to find problems openly, where the parties invited to the interview are asked for their opinions, ideas (Creswell, 2017). In this study, as many as 20 persons with disabilities, special education graduates were interviewed, which were grouped as follows: (a) 10 persons with disabilities sitting in wheelchairs who were rejected to work in the company, (b) 10 persons with disabilities consist of: 5 handicapped persons sitting in wheelchairs, and 5 people with hearing impaired who used to work in private companies but finally decided to stop working. This grouping is intended to see how each person with a disability gets experience and treatment related to the world of work. The researchers were assisted by the sign language interpreter when interviews with people with hearing impairments. Due to thr ethical issues and objections from the informants, the names of the informants and companies are written only in initials. In this study, the researchers also interviewed a public policy expert to obtain information on how policies related to the rights of persons with disabilities were implemented (Asih, 2014; Wattimena, 2020).

Data analysis is an effort made by working with data, sorting it out, organizing and turning the data into manageable units, synthesizing it, looking for and finding patterns, finding out what is important and what is learned, and finding what can be told to others. others (Moleong, 2005: 248). Data analysis is carried out continuously, taking place during data collection and after data collection is complete (Sugiyono, 2019).

In phenomenological research, there are structured and specific analytical methods (Creswell, 2017; Mitchell et al., 2020) namely: (a). Describe personal experience with the phenomenon being studied; (b). Make a list of important statements; (c). Taking these important statements then grouped into meaning units or themes; (d). Write a textural description (what is experienced) of the participant's experience; (e). Describing a structural description (how the experience occurred).

\section{RESULTS AND DISCUSSION}

The results of the researcher's interviews with informants consisting of 10 people with disabilities who were rejected by the company and 10 people with disabilities who had worked in the company but finally decided to stop working are as follows: 
1) Data of disabilities who were rejected by private companies

From the interview with 10 people with disabilities who were rejected by private companies, it is known that they have tried to apply for a job for over 40 times. First, they sent their application letter and supporting documents via email and then they were called for an interview. They were aware of the physical conditions that required them to sit in a wheelchair, therefore when they applied, the positions they put forward were jobs that were possible for them to do namely receptionists, customer service and administrative staff. They also have a high school diploma from Special School which means that they are equivalent to general high school graduates and even more fluent in English than general high school graduates. However, unfortunately when they were called for an interview, they failed.

"I have sent application letters more than 40 times to private companies. The positions that I proposed were also like customer service, receptionist or administrative staff, because I think these jobs can be done without having to leave my seat. I am also quite fluent in English, so I think it will be a plus for me. But unfortunately, I always fail after the interview process. They always promised to call me back but after that I never heard from them again, so I then assumed that the company would only recruit non-disabled prospective employees. Right now, I don't expect to work in a company anymore, but I want to build my own business and I will recruit friends with disabilities to work together." (UT- handicapped person, 24 years old)

The results of the interview above are in line previous study which says that in managing human resources with disabilities, companies must understand how to respect differences, especially how to communicate with people with disabilities, which naturally will pose challenges related to how to treat and fulfill the needs of people with disabilities, such as facilities and infrastructure for persons with disabilities. It is unfortunate that there are still many large companies in Indonesia that do not have the awareness to employ persons with disabilities even though there is Law Number 8/2016 which states that companies must employ at least $1 \%$ of the total number of employees (Agustina \& Mahfudz, 2020; Beatty et al., 2019).

2) Data of disabilities who have worked in private companies but then resigned.

Of the ten former employees of private companies interviewed, data was obtained that the company only paid attention to them in the early days of their work for the first 2 years, but after that, they felt the company paid less attention to them. This can be seen from how the different treatment perceived by disabled employees.

"In the early days, the company seemed to be trying to accommodate the needs of me and my friends with disabilities, especially in terms of facilities and infrastructure, namely toilets provided specifically for people with disabilities, entrances to the office with wheelchair access. In addition, the HRD staff always asked if my friends and I had any problems or not, etc. As I recall, after 1 month I worked, the company was visited by officials from the Ministry of Manpower and I was asked for an interview. However, after about 5 years running, my friends and I feel less involved in the various programs and activities they run, for example in training activities, 
especially if the training is held outside the office, with the reason that they will be included in the next term. In addition to promotion which was never considered. After 5 years of being customer service, I once proposed to be promoted to supervisor. But it turned out that I failed and my friend who is not a disabled person and has only worked for 3 years was selected to be a supervisor."

(ER- disabled handicap, 23 years old).

"Since I have a hearing impairment, I was placed as an administrative officer who mostly did secretarial work. At first I was accompanied by a sign language interpreter who was my teacher at Special School, and was recruited by the company. In the early days I felt very comfortable working in a large company of UNI's caliber. However, after two years of working, I felt uncomfortable because first, the company did not involve me in many activities, secondly, the existing employees were less welcome with my presence. They also din't want to communicate with me. The professional sign language translator initially provided by the company, later was terminated for reasons of budget efficiency. I also felt that the company did not socialize the existence of employees with disabilities and did not prepare its employees to be able to appreciate differences. This uncomfortable situation finally forced me to decide to quit the job. (US- person with hearing impairment, 24 years old).

From the interviews conducted, it was found that companies only recruited persons with disabilities to fulfill the $1 \%$ quota required in order to receive a favorable assessment from the government. However, the companies actually did not understand the management of human resources for persons with disabilities. This is in line with previous study which states that people with disabilities also face difficulties in job promotion (Paikah, 2017). This problem is also closely related to the difficulties experienced by persons with disabilities in increasing wages (Cho \& Kim, 2021).

\section{3) Data of Public Policy practitioners}

The results of an interview with a public policy expert obtained data that in Law Number 18/2018, Article 11 has affirmed the sanctions for companies/people who hinder and/or prohibit persons with disabilities from obtaining the right to get a job subject to sanctions, namely imprisonment for a maximum of 2 years and a maximum fine of IDR 200 million. But unfortunately, until now the public has never heard of a company being subject to criminal sanctions even though the company does not want to employ people with disabilities at all. In general, the reason is the inadequate facilities and infrastructure for persons with disabilities. Meanwhile, the cause of the weak implementation of the regulation is due to the overlapping authority of supervision and sanctions against companies between the Manpower Office and the Social Service.

In addition, the government must also establish a Disability Service Unit in the regions. The establishment of disability service units in the regions aims to plan for the protection and fulfillment of the rights to employment of persons with disabilities, provide information on recruitment, job training, job placement, work continuity and career development, and assist employers who employ persons with disabilities and assist persons 
with disabilities themselves in finding a job. Until now, there is no implementing regulation that regulates the establishment of Disability Service Units in the regions.

However, the government through the Ministry of Manpower said that private companies were aware of employing persons with disabilities. In fact, it is claimed that private companies have almost fulfilled the $1 \%$ quota. However, there has never been any data regarding the number of companies that have employed persons with disabilities and which have met the $1 \%$ quota. There has been no effective implementation effort from the government regarding the rights of persons with disabilities. Whereas these rights are guaranteed by their respective constitutions at least in Article 28H paragraph 2, Article 28I paragraph 1 and paragraph 2 and Article 28J of the 1945 Constitution.

Actually there is a promise of incentives from the government to encourage its implementation. Several forms of incentives promised are easy licensing, awards, and the provision of accessible work facilities. Unfortunately, the Government Regulation that regulates these incentives has not yet been issued. In essence, there must be stricter supervision of companies regarding the fulfillment of a quota of persons with disabilities of at least 1\% and if the government is to provide incentives to companies that employ persons with disabilities, then the regulations or policies must be made immediately, in order to encourage more companies to immediately employ persons with disabilities.

\section{CONCLUSION}

The results of this study indicate that Law Number 8/2016, related to the obligation of employers to employ persons with disabilities, has not been implemented optimally. Even though in Law Number 8/2016, Article 11 has been explicitly stated that for companies that refuse persons with disabilities or prevent persons with disabilities from obtaining their rights to work, they will be sentenced to a maximum imprisonment of 2 years and a maximum fine of Rp. 200 million. However, so far no company has been sanctioned. This proves that the supervision carried out by the government is not running well and it is also caused by the overlapping regulations involving different agencies, namely the Ministry of Manpower and the Ministry of Social Affairs, including providing incentives for companies that employ persons with disabilities. Companies that employ persons with disabilities are still weak in their management even though there are guidelines for managing human resources with disabilities, which were prepared by the International Labor Organization (ILO). For further research, the researcher suggests that research related to government supervision of companies that do not want to employ persons with disabilities should be carried out with a different approach.

\section{REFERENCES}

Agustina, R., \& Mahfudz. (2020). Peran Manajemen Keragaman Budaya dalam Kinerja Organisasi Non Profit Berbasis Aliansi (Studi Kasus Pada Jakarta Centre For Law Enforcement Cooperation). Diponegoro Journal of Economics, 9(1), 25-42. https://ejournal3.undip.ac.id/index.php/jme/article/view/31488/25638

Amrullah, R., Ismail, T., \& Uzliawati, L. (2018). Pengaruh Budaya Organisasi, Intellectual Capital dan Keragaman Pengukuran Kinerja Terhadap Kinerja Organisasi (Study Empiris 
Accessibility for Persons with Disabilities in Employment Opportunities in Private Companies: A Case Study of Indonesia

Poernomo, Omboto, Tinka

Perusahaan Manufaktur di Provinsi Banten). Jurnal Riset Akuntansi Universitas Sultan Agung Tirtayasa, 3(2), 221-240. https://doi.org/http://dx.doi.org/10.48181/jratirtayasa.v3i2.5499

Angeloni, S. (2013). Integrated Disability Management. SAGE Open, 3(4), 215824401351030. https://doi.org/10.1177/2158244013510303

Asih, I. D. (2014). Fenomenologi Husserl: Sebuah Cara "Kembali Ke Fenomena". Jurnal Keperawatan Indonesia, 9(2). https://doi.org/10.7454/jki.v9i2.164

Bam, A., \& Ronnie, L. (2020). Inclusion at the Workplace: An Exploratory Study of People with Disabilities in South Africa. International Journal of Disability Management, 15, e6. https://doi.org/10.1017/idm.2020.5

Beatty, J. E., Baldridge, D. C., Boehm, S. A., Kulkarni, M., \& Colella, A. J. (2019). On the treatment of persons with disabilities in organizations: A review and research agenda. Human Resource Management, 58(2), 119-137. https://doi.org/10.1002/hrm.21940

Bonnell, K., Michalovic, E., Koch, J., Pagé, V., Ramsay, J., Gainforth, H. L., Lamontagne, M.-E., \& Sweet, S. N. (2021). Physical activity for individuals living with a physical disability in Quebec: Issues and opportunities of access. Disability and Health Journal, 14(3), 101089. https://doi.org/10.1016/j.dhjo.2021.101089

Bourke, J. A., Nichols-Dunsmuir, A., Begg, A., Dong, H., \& Schluter, P. J. (2021). Measuring disability: An agreement study between two disability measures. Disability and Health Journal, 14(2), 100995. https://doi.org/10.1016/j.dhjo.2020.100995

Budiati, I., Riyadi, Larasaty, P., Pratiwi, A. I., Saputri, V. G., Meilaningsih, T., Kurniasih, A., Hastuti, A., Anam, C., \& Hartini, S. (2020). Indikator Kesejabteraan Rakyat 2020 (W. P. Adi \& I. Budiati (eds.); 1st ed.). BPS-Statistic Indonesia. https://www.bps.go.id/publication/2020/11/30/5d97da0e92542a75d3cace48/indikatorkesejahteraan-rakyat-2020.html

Centers for Disease Control and Prevention. (2020). Disability and Health Overview. Disability and Health Promotion.

https://www.cdc.gov/ncbddd/disabilityandhealth/disability.html\#: :text=According to the World Health Organization $\% 2 \mathrm{C}$ disability has three dimensions\%3A\&text=Impairment in a person's body, $\% 2 \mathrm{C}$ walking $\% 2 \mathrm{C}$ or problem solving.

Cho, M., \& Kim, K. M. (2021). Exploring the disparity in tangible outcomes of internet use between persons with disabilities and persons without disabilities in South Korea. Disability and Health Journal, 14(3), 101101. https://doi.org/10.1016/j.dhjo.2021.101101

Creswell, J. W. (2017). Research Design Pendekatan Kualitatif, Kuantitatif, dan Mixed (S. Z. Qudsy (ed.); 3rd ed.). Pustaka Pelajar. https://opac.perpusnas.go.id/DetailOpac.aspx?id=1213690

Eisenberg, Y., Vanderbom, K. A., Harris, K., Herman, C., Hefelfinger, J., \& Rauworth, A. (2021). Evaluation of the Reaching People with Disabilities through Healthy Communities Project. Disability and Health Journal, 14(3), 101061. https://doi.org/10.1016/j.dhjo.2021.101061

Gerak Inklusi. (2021). UU 8 Tabun 2016 tentang Penyandang Disabilitas. Gerakinklusi.Id. https://www.gerakinklusi.id/politik/uu-8-2016-penyandang-disabilitas

Havercamp, S. M., Barnhart, W. R., Robinson, A. C., \& Whalen Smith, C. N. (2021). What should we teach about disability? National consensus on disability competencies for health 
Accessibility for Persons with Disabilities in Employment Opportunities in Private Companies: A Case Study of Indonesia

Poernomo, Omboto, Tinka

care education. Disability and Health Journal, 14(2), 100989.

https://doi.org/10.1016/j.dhjo.2020.100989

International Labour Organization. (2013). Code of practice on managing disability in the workplace (1st ed.). International Labour Organization. https://www.ilo.org/global/topics/disability-andwork/WCMS_475650/lang--en/index.htm

Jackson, H., Young, N. A. E., \& Taylor, D. (2021). Beyond question wording: How survey design and administration shape estimates of disability. Disability and Health Journal, 14(4), 101115. https://doi.org/10.1016/j.dhjo.2021.101115

Jamali, H. R. (2018). Does research using qualitative methods (grounded theory, ethnography, and phenomenology) have more impact? Library \& Information Science Research, 40(3-4), 201207. https://doi.org/10.1016/j.lisr.2018.09.002

Larocca, V., Fraser-Thomas, J., \& Bassett-Gunter, R. (2020). "Even if someone has a physical disability, they can still participate": Youth with physical disabilities' motivational physical activity message preferences. Disability and Health Journal, 13(1), 100845. https://doi.org/10.1016/j.dhjo.2019.100845

Lloyd, P. A., Briggs, E. V., Kane, N., Jeyarajah, A. R., \& Shepherd, J. H. (2014). Women's experiences after a radical vaginal trachelectomy for early stage cervical cancer. A descriptive phenomenological study. European Journal of Oncology Nursing, 18(4), 362-371. https://doi.org/10.1016/j.ejon.2014.03.014

Mitchell, D., Byron, E. T., Cross, J. B., Oleka, O. J., Van Eps, S. N., Clark, P. L., \& Sajko, N. S. (2020). Going in thinking process, coming out transformed: Reflections and recommendations from a qualitative research course. Social Sciences \& Humanities Open, 2(1), 100031. https://doi.org/10.1016/j.ssaho.2020.100031

Nuraviva, L., Harsasto, P., \& Alfirdaus, L. K. (2018). Aksesibilitas Penyandang Disabilitas Terhadap Pelayanan Publik di Kota Surakarta. Journal of Politic and Government Studies, 7(1), 1 10. https://ejournal3.undip.ac.id/index.php/jpgs/article/view/19073

Nursyamsi, F., Arifianti, E. D., Aziz, M. F., Bilqish, P., \& Marutama, A. (2015). Kerangka Hukum Disabilitas Di Indonesia: Menuju Indonesia Ramah Disabilitas (1st ed.). Pusat Studi Hukum dan Kebijakan Indonesia (PSHK). https://www.pshk.or.id/wpcontent/uploads/2016/01/Kerangka-Hukum-Disabilitas-di-Indonesia.pdf

Ordway, A., Garbaccio, C., Richardson, M., Matrone, K., \& Johnson, K. L. (2021). Health care access and the Americans with Disabilities Act: A mixed methods study. Disability and Health Journal, 14(1), 100967. https://doi.org/10.1016/j.dhjo.2020.100967

Paikah, N. (2017). Implementasi Undang-Undang Nomor 8 Tahun 2016 Tentang Penyandang Disabilitas Dalam Perlindungan dan Pemenuhan Hak Penyandang Disabilitas Di Kabupaten Bone. Jurnal Penelitian Hukum Dan Pendidikan EKSPOSE, 16(1), 335-348. https://doi.org/http://dx.doi.org/10.30863/ekspose.v16i1.91

Pertiwi, P., Llewellyn, G., \& Villeneuve, M. (2020). Disability representation in Indonesian disaster risk reduction regulatory frameworks. International Journal of Disaster Risk Reduction, 45, 101454. https://doi.org/10.1016/j.ijdrr.2019.101454

Pramesty, T. (2020). Implementasi Undang-Undang Nomor 8 Tabun 2016 Tentang Penyandang Disabilitas Perspektif Hukum Islam [Universitas Islam Negeri Raden Intan Lampung]. http://repository.radenintan.ac.id/11941/1/BAB II.pdf 
Accessibility for Persons with Disabilities in Employment Opportunities in Private Companies: A Case

Putra, P. S. (2019). Aksesibilitas Perlindungan Hukum Bagi Tenaga Kerja Penyandang Disabilitas di Kabupaten Karawang. Mimbar Hukum - Fakultas Hukum Universitas Gadjah Mada, 31(2), 205. https://doi.org/10.22146/jmh.44200

Putra, R. E. (2020). Implementasi Undang Undang Nomor 8 Tabun 2016 Tentang Hak Politik. Penyandang Disabilitas Dalam Perspektif Fiqh Siyasah [Universitas Islam Negeri Raden Intan Lampung]. http:// repository.radenintan.ac.id/10164/1/PUSAT 1 2.pdf

Saputra, R. (2021). Pengaruh Keragaman Budaya Karyawan dan Komunikasi Organisasi Terhadap Kinerja Karyawan di PT Indosurya Sukses. Jurnal Ilmu Komunikasi PROLOGIA Universitas Tarumanegara, 5(2), 1-13. https://doi.org/http://dx.doi.org/10.24912/pr.v2i1.2399

Stillman, M. D., Ankam, N., Mallow, M., Capron, M., \& Williams, S. (2021). A survey of internal and family medicine residents: Assessment of disability-specific education and knowledge. Disability and Health Journal, 14(2), 101011. https://doi.org/10.1016/j.dhjo.2020.101011

Sugiyono. (2019). Metode Penelitian Kuantitatif Kualitatif dan R\&D (I). Alfabeta. https://cvalfabeta.com/product/metode-penelitian-kuantitatif-kualitatif-dan-rd-mpkk/

Susanto, E., \& Sudiro. (2018). Studi Kajian Tingkat Aksesibilitas Pada Fasilitas Publik Bagi Penyandang Disabilitas (Berkebutuhan Khusus) di Kota Surakarta. Jurnal Penelitian Dan Pengabdian Masyarakat SAINSTECH, 5(1), 19-32.

http://sainstech.poltekindonusa.ac.id/index.php/view/article/view/10

Triutari, I. (2014). Persepsi Mahasiswa Penyandang Disabilitas Tentang Sistem Pendidikan Segregasi Dan Pendidikan Inklusi. Jurnal Penelitian Pendidikan Khusus UNP Padang, 3(3), 221 229. https://doi.org/https://doi.org/10.24036/jupe38470.64

Wahyuni, D. (2019). Peluang dan Tantangan Penyandang Disabilitas di Dunia Kerja. Jurnal Kesejabteraan Sosial Pusat Penelitian DPR-RI, 11(23), 13-18. https://berkas.dpr.go.id/puslit/files/info_singkat/Info Singkat-XI-23-I-P3DI-Desember2019-218.pdf

Wardani, F. C., Kismartini, \& Rostyaningsih, D. (2015). Evaluasi Ketersediaan Fasilitas dan Aksesibilitas Bagi Penyandang Cacat pada Gedung BPJS Kesehatan Kota Semarang. Journal Of Public Policy And Management Review, 4(3), 1-10. https://doi.org/https://doi.org/10.14710/jppmr.v4i3.8865

Wattimena, R. A. A. (2020). Fenomenologi Edmund Husserl. Rumah Filsafat. https://rumahfilsafat.com/2009/08/19/fenomenologi-edmund-husserl/

Widyawati, Y., Scholte, R. H. ., Kleemans, T., \& Otten, R. (2021). Positive parenting and its mediating role in the relationship between parental resilience and quality of life in children with developmental disabilities in Java Island, Indonesia. Research in Developmental Disabilities, 112, 103911. https://doi.org/10.1016/j.ridd.2021.103911

World Health Organization. (2015). WHO Global Disability Action Plan 2014-2021. https://www.who.int/publications/i/item/who-global-disability-action-plan-2014-2021

Ziakas, V., \& Boukas, N. (2013). Extracting meanings of event tourist experiences: A phenomenological exploration of Limassol carnival. Journal of Destination Marketing \& Management, 2(2), 94-107. https://doi.org/10.1016/j.jdmm.2013.02.002 